\title{
Overcoming the capital investment hurdle in worker-controlled firms
}

\author{
Guy Major \\ School of Biosciences, Cardiff University, Cardiff, UK, and \\ Jonathan Preminger \\ Cardiff Business School, Cardiff University, Cardiff, UK
}

Overcoming the capital investment hurdle

\begin{abstract}
Purpose - Both the academic literature and practitioners have long noted the need for an equity investment mechanism for worker-controlled firms that alleviates investor anxieties without undermining internal workplace democracy. The purpose of this paper is to outline one such possible mechanism.

Design/methodology/approach - The proposal locks together the interests of workers and external investors, via non-voting shares with dividends set by a pre-agreed value-added sharing formula. Each worker is paid a base wage, with the average across the firm being a pre-defined multiple of the national minimum wage. Any additional surplus is split into a number of equal "slices", with each share receiving one slice as its dividend, and the average worker receiving a pre-agreed number of slices as a bonus.

Findings - Workers have an incentive to maximise their own incomes, and in so doing, will also automatically maximise the dividends received by investors, obviating the need for the shares to have normal voting rights. Working on this principle of aligned interests, the authors also discuss reinvestment, worker ownership of non-voting shares and possibilities for a secondary share market. The authors show how this proposal will be a significant step in aligning the interests of investors with owner-workers in a democratic, negotiated way that shares both risk and returns, thus making worker-controlled firms more attractive to equity investment.

Originality/value - In light of the recognised problem of underinvestment in worker-controlled firms and the risk of their degeneration, this paper will interest both academics and practitioners in employee ownership, co-operatives and various forms of workplace democracy.
\end{abstract}

Keywords Equity, Underinvestment, Workplace democracy, Degeneration, Non-voting share,

Value-added sharing

Paper type Conceptual paper

\section{Introduction}

There is increasing popular suspicion that the current economic system dominated by shareholder corporations has "failed" (Bakan, 2004), particularly since the economic crisis of 2008 (Birchall, 2017). The pathologies of this hyper-competitive globalised system (Scholtz and Schneider, 2016; Srnicek, 2018), its corrupting influence (Klein, 2007) and its environmental destruction (Hawken, 2010) are increasingly under scrutiny, particularly in light of the drastically skewed distribution of income, wealth and power (IPPR, 2018; Norton and Ariely, 2011; Oxfam, 2018). While the problems of contemporary capitalism are myriad, such as the rigging of markets by monopolistic behaviour (Srnicek, 2018), at the core of the issue is a shareholding structure that decouples ownership and control in a way that damages investors but also workers: holding companies, cross-ownership and investment funds all exacerbate the democratic deficit in capitalist firms (Erdal, 2011). Workers are merely a "resource", to be exploited like any other (Ridley-Duff and Bull, 2016).

One response to this popular suspicion of "the system" and awareness of its pathologies has been growing political support for mixed market economies with a range of ownership

(C) Guy Major and Jonathan Preminger. Published by Emerald Publishing Limited. This article is published under the Creative Commons Attribution (CC BY 4.0) licence. Anyone may reproduce, distribute, translate and create derivative works of this article (for both commercial \& non-commercial purposes), subject to full attribution to the original publication and authors. The full terms of this licence may be seen at http://creativecommons.org/licences/by/4.0/legalcode

Received 26 January 2019 Revised 24 June 2019 Accepted 5 September 2019

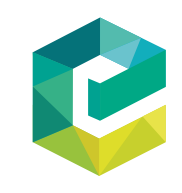

Journal of Participation and Employee Ownership Emerald Publishing Limited DOI 10.1108/JPEO-01-2019-0001 
structures (Barrott et al., 2017; Erdal, 2011), which has received the explicit blessing of past UK Governments (Bryson and Freeman, 2010; Pendleton, 2011; Pendleton and Robinson, 2017). Employee ownership in particular is perceived to address the need for a new era of economic development which is "sustainable environmentally, economically, and socially" (Michie, 2017). Employee ownership has also been given a government boost in the UK, in the form of the Finance Act of 2014 which granted significant tax advantages to owner-founders selling their businesses to employees, as well as to the employees themselves. Employee Stock Ownership Plans (ESOPs) and other forms of employee ownership or "shared capitalism" have for a long time benefited from significant tax breaks in the USA (Kruse et al., 2010), and numerous other governments also provide fiscal incentives (Erdal, 2011; Michie et al., 2017).

There are numerous examples of worker co-operatives around the world, such as the famous Mondragon co-ops in Spain (Barandiaran and Lezaun, 2017), worker co-ops in the Emilia Romagna region of Italy (Logue, 2006), and a thriving worker co-op movement in France (Pérotin, 2017), as well as a large variety of different structures of wholly or partly employee-owned firms (Blasi et al., 2017; Pendleton and Robinson, 2017) or firms controlled by trusts for the benefit of their workers, such as the John Lewis Partnership, Tullis Russell (Erdal, 2011), or more recently, Richer Sounds. Trust-controlled firms typically involve a strong element of common ownership, often with some kind of "asset lock" to prevent demutualisation (Pérotin, 2017) and the temptation of "selling out" to an external buyer or buyers, for example to achieve a windfall for the workers (Roberts, 2000).

In many ways, however, the biggest real-world "laboratory" experiment in employee ownership is to be found in the US. Approximately $14 \mathrm{~m}$ workers are employed by around 6,500 companies with some kind of employee share ownership scheme, with assets totalling $\$ 1.4$ trillion (National Center for Employee Ownership, 2019a). In total, 100 per cent employeeowned firms are thought to account for around 30-40 per cent of this growing and vibrant sector, and a far greater fraction are majority employee-owned with strong elements of democratic and/ or participatory governance (National Center for Employee Ownership, 2019b)[1].

Indeed, employee ownership as increasingly practiced facilitates various levels of employee control, and firms which move away from the shareholder/manager structure usually aspire to some level of workplace democracy (Meyers, 2011). Moreover, there is growing body of evidence showing the substantial benefits in terms of the firm's sustainability and resilience, "static" productivity, income, and worker job satisfaction and health which stem from the combination of profit sharing, employee ownership[2] and the flattening of workplace hierarchies along with some form of participatory or democratic management[3] and "ownership culture" (Blasi et al., 2017; Fakhfakh et al., 2012; McDonnell, 2012; Nuttall, 2012; Pérotin, 2017; Rosen, 2011)[4]. Workplace democracy and employee ownership, as well as being about sharing the pie more fairly, are also about growing the pie more effectively - in a better and possibly greener way (Fakhfakh and FitzRoy, 2018).

However, as with all experiments, things go wrong and unanticipated challenges arise. There is a need for new, imaginative solutions to several inter-related, stubborn, recurring problems (Major, 1996). We present one solution, non-voting surplus-sharing shares, with dividends locked to average bonuses, which we believe could be transformative across a wide range of different company structures.

This solution aims to address investor concerns about the move towards democratic control: Can we trust workers who are fully in charge? What would stop them raising their own wages at the expense of investors? What would be their incentives to invest in their firm themselves? Would they be competent to run it, or to elect leaders who were? Conventional wisdom asserts that too few of us will invest in a firm, unless we can protect our investment by having someone in charge who actively pursues and protects our interests (McCain, 1999). While there is some recent counter-evidence (Fakhfakh et al., 2012; 
Pérotin, 2017), it seems that democratic worker-controlled firms still generally find it hard to attract capital (Barrott et al., 2017; Employee Ownership Association, 2012; Erdal, 2011; McDonnell, 2012; Nuttall, 2012).

The issue can be framed in terms of risk. However, in conventional ownership structures, risk is not limited to investors. While workers would clearly be taking a substantial risk by putting "too much" of their own money into their firm, they also take big risks by being employed by that firm. Their wages could be reduced, they could be made redundant and lose their livelihoods, or they could end up in far lower-paid jobs. Risk and control are substantially decoupled in most capitalist firms, both for ordinary investors and for workers (Erdal, 2011; McCain, 1999), and this may be one root cause of much of the system-wide dysfunction and hyper-concentration of wealth in the modern economy (IPPR, 2018; Norton and Ariely, 2011; Oxfam, 2018).

This paper discusses this age-old problem of risk (Pérotin and Robinson, 2004), and builds on the "FairShares" idea and related models (Major, 1996, 1998; Ridley-Duff, 2015a, b, 2018; Ridley-Duff and Bull, 2016) to propose an ownership structure that couples dividends to pay, going some way to linking risk and control and thus enabling true workplace democracy to thrive while protecting investors. First we discuss the problem of underinvestment and the danger of an employee-controlled firm "degenerating" back into a standard shareholder structure. We then present our proposal for tradeable, non-voting, surplus-sharing shares which lock together the interests of workers and investors, thereby reducing investor risk in worker-controlled firms and thus increasing the possibilities for investment. We also discuss some complementary mechanisms to further regulate the relationship between investors and workers. We assert that this share structure will solve the problems of underinvestment in workplace democracies while preventing the slide back into standard shareholder structures. At the same time, it will improve investor protection by coupling dividends to bonuses, by incentivising and motivating the workforce, and by protecting the workers' stakes in their own firm. In the Appendices A1-A7, we work through some examples to illustrate our proposal.

\section{Underinvestment}

Despite impressive advances in employee ownership in the USA and UK in recent years (Michie et al., 2017), as well as various forms of worker takeover of failing firms (Ozerow and Croucher, 2014; Vieta, 2010, 2012), there are still comparatively few democratic worker-controlled firms in the world (Barrott et al., 2017). Ruthless Darwinian selection may be part of the explanation: historically, many worker co-operatives have tended to suffer from underinvestment, both due to an inability to attract external capital, and due to a reluctance of workers to reinvest profits (Major, 1996, 1998). Democratic firms find it hard to attract investment, either internal or external, because they are seen (unfairly?) as too risky for both workers and investors, and as not providing adequate returns on capital. Clearly, there are fewer opportunities for capital to extract value from labour in worker-controlled firms. Also, worker-controlled firms are frequently ideologically hostile to seeking external capital, and structure themselves to prevent it (Pérotin, 2017). Depending on the country, there are other barriers such as tax incentives that restrict external investment, lack of awareness among investors and public sector purchasing decision-makers, lack of appropriate financial instruments for investing in employee-owned firms (Employee Ownership Association, 2012), and inadequate government support (Knell, 2008). Workercontrolled firms struggle therefore, in many countries and industries, to achieve an optimal mix of capital and labour to maximise productivity, innovation and growth (dynamic" productivity) - and can be out-competed by capitalist firms (Barrott et al., 2017; Major, 1996).

In the UK, the most popular model for employee ownership is fast becoming the employee trust (Pendleton and Robinson, 2017), which in effect holds shares collectively in the employees' names. However, in many cases, there is still an unmet need to attract much
Overcoming the capital investment hurdle 
greater risk-sharing "equity-like" capital (Employee Ownership Association, 2012; Nuttall, 2012), despite the existence of several organisations specialising in lending to employeeowned firms (e.g. the Co-op Loan Fund, Unity Trust Bank). Such debt finance absorbs or shares far less risk than equity finance, due to the need to pay relatively fixed interest (as opposed to variable or discretionary dividends), and this may become a further drag on the company if interest rates go up. The requirement to pay back or refinance the loan amount itself (the principal) is an additional serious drawback - again, not suffered by equity finance.

At a very basic level, if one wants to invest risk-sharing, non-repayable equity in workercontrolled or majority employee-owned businesses, without subverting their internal democracy, there are still relatively few easy ways to do it (Employee Ownership Association, 2012; Nuttall, 2012). There are even fewer ways to do it while having in place credible protections that substitute for direct control or control "by proxy" - relying on a bigger or controlling shareholder with similar interests, better information and sufficient power (McCain, 1999). Investing in worker-controlled firms still seems more like a charitable or ideological act, rather than one born of mutual interest.

One more issue is that if workers cannot extract a reasonable portion of "their" hard-won equity from a firm, they have a reduced incentive to work towards internally generating equity (or reinvesting) in the first place. Crucially, the results of lack of reinvestment can lead firms to "degenerate" back into a standard shareholder structures.

\section{Degeneration}

Both financially stressed and successful worker co-ops and worker-owned firms have often tended, eventually, to "degenerate" back to capitalist control (Barrott et al., 2017; Major, 1996, 1998; Pencavel, 2013). In the case of successful worker co-ops, this may be related to workers' inability to extract valuable equity - or, conversely, in the case of employee-owned businesses, being able to do so too easily, and in the process relinquishing democratic control. Many in the field now believe degeneration is ultimately more problematic than underinvestment, although others disagree (Employee Ownership Association, 2012; Nuttall, 2012). Degeneration has been particularly prevalent among certain types of non-coop employee-owned firms. For example, relatively recently, all UK bus companies that were privatised into employee ownership "sold out" back to concentrated capitalist control (Pendleton and Robinson, 2017; Spear, 1999), thanks largely to non-wealthy workers being, in effect, "bribed" by substantial windfalls - mostly unearned (Roberts, 2000).

A somewhat related problem occurs in many thriving worker co-ops; longer-standing workers may have ploughed back considerable time and earnings ("sweat equity"), and taken big risks over the years, so they become increasingly reluctant to cede control to newer "freeloaders". A number of counter-measures have been devised, such as entry/ membership fees, asset locks (indivisible/non-distributable equity), or holding non-transferrable worker shares in a trust, (Pendleton and Robinson, 2017; Pérotin, 2017). All of these have potential drawbacks resulting from workers' reduced ability to extract "their" full equity, and may result, therefore, in unintended disincentives, such as reduced internal reinvestment, and in the case of entry fees, recruitment difficulties (Major, 1996; McDonnell, 2012). The trade-offs, of course, depend on what motivates different individuals at different stages of their lives including the perceived benefits of being in a good working environment.

There are notable exceptions of long-lived worker co-ops which have also grown successfully - such as the Mondragón Co-operative Corporation, in the Basque Country, Spain (Barandiaran and Lezaun, 2017), the Emilia Romagna co-operative network in Italy (Logue, 2006) and the SCOP co-ops in France (Fakhfakh et al., 2012; Pérotin, 2017). The Mondragón group partly solved underinvestment by a federal structure with a "popular 
labour bank" (Caja Laboral Popular) at its heart, and by a system of interest-bearing internal capital accounts which partially separates ownership from control but does not really reflect true equity, i.e. the full commercial value of the companies. The group has, out of pragmatism, taken on large numbers of non-voting employees - but is in the process of re-democratising (Barandiaran and Lezaun, 2017). We will argue that the non-voting surplus-sharing equity shares outlined below could help resolve the investment/equity/ democracy dilemmas facing Mondragón and a broad range of other worker-controlled or employee-owned firms, ESOPs or possible converts. Surplus-sharing shares could also be an equity investment vehicle for small and medium enterprises in general, where founders commonly want to maintain control while attracting external risk-sharing investment.

\section{Value-added sharing}

Our proposal overcomes the underinvestment and degeneration problems of democratic worker-controlled firms by tightly locking together the interests of workers and investors. Workers could then democratically control firms, but would automatically look after investors (themselves included), in the process of optimising their own incomes, job security and the long-term prospects of the firm. We build on an elegant mechanism originally devised by Roger McCain of Drexel University (McCain, 1977, 1999) which makes a firm's average worker[5] equivalent to a pre-agreed number of shares, $k$. The firm's value-added $(=$ sales minus non-labour costs)[6] is split equally among a number of "slices of the cake". Each share gets one slice as its dividend, and each worker gets $k$ slices as their variable pay (averaged across all workers). So the total number of slices is equal to the (number of shares) $+k \times$ (the number of full-time equivalent workers). If there are $S$ shares and $W$ workers (FTE), there will be $(S+k W)$ slices, so for value-added $£ V$, each slice will be $£ V /(S+k W)$. Shares could be non-voting under normal conditions, and the firm could then be governed democratically, by one-worker one-vote. Part-time workers may be granted pro-rated fractional votes.

\section{Tradeable, (normally) non-voting, surplus-sharing shares}

In some firms, this scheme for value-added sharing might result in overall pay being too variable or too unpredictable. A deal-breaker for most workers is that pay could drop too low in bad years. This could be mitigated by some kind of national living wage top-up or by pay insurance (including between federated worker-controlled firms). In addition, the first tranche of a firm's value-added could be allocated to a traditional fixed component of wages, or "Base Pay" (see Figure 1), up to a pre-agreed multiple of the national minimum wage (averaged over all the workers: some could get more, others less). Any "surplus" $P$ (loosely, "profit") above that could then be split equally between all slices: i.e. between shares (as dividends) and workers (now as bonuses): each slice is now $£ P /(S+k W)$. The average worker gets $k$ slices (on top of base pay), i.e. an average bonus of $£ k P /(S+k W)$. Each share still gets one slice as its dividend.

A generic example is shown in Figure 1 (see Appendices A1-A7 for more detailed examples). Workers would have an incentive to maximise their average earnings. But in order to do this, they would also have to maximise earnings per share, hence dividends, and would thus automatically pursue and protect the interests of the investors. This would apply over the longer term too, via the workers also aiming for job security and growth. The firm could be democratically controlled by its workforce, yet investors' interests (long-term dividend and share value maximisation) would be ensured as an inherent, built-in part of the arrangement, by being tightly locked to the workers' overall incomes and prospects.

In order to provide reasonable cash flow to workers, part of the projected annual bonus could be paid as a monthly bonus advance, or bonuses could be calculated on a monthly basis, retaining a safety margin till the year end.
Overcoming the capital investment hurdle 
JPEO

Figure 1.

Surplus sharing
VALUE ADDED

(sum of all boxes)

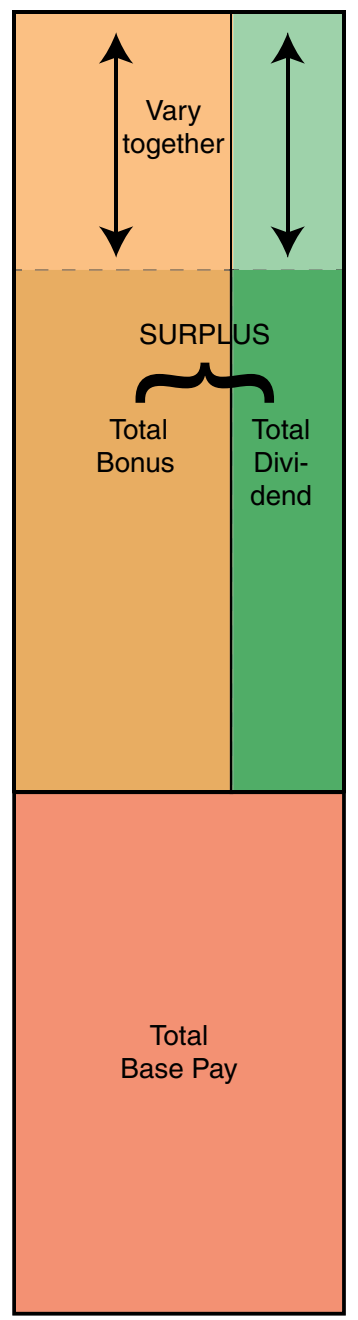

(Areas proportional to money)

Notes: Surplus is value-added minus total base pay. It is divided between a number of equal "slices"; each share receives one slice as its dividend; average worker is paid a pre-agreed number ( $\mathrm{k}$ ) of slices as their bonus. If surplus increases, bonuses and dividends increase proportionately

The allocation of the $k W$ workers' slices between the $W$ different workers (FTE) is decided democratically. Under this surplus-sharing scheme, different workers can be paid different numbers of surplus (profit) slices, reflecting skill/scarcity, hours, recruitment difficulty or danger, or according to other democratically-agreed criteria, so long as the average number of slices per full-time equivalent worker is kept to the pre-agreed number $(k)$ - or more practically within some pre-agreed range (so that workers cannot undercut investor dividends by voting 
to pay themselves more or work less hours). This also means a particular worker's allocation of slices may need to be adjusted when other workers join or leave.

As an additional layer of protection, perhaps investors' prior approval should be needed before the total fraction of surplus going to workers' bonuses is allowed to increase beyond a pre-agreed but renegotiable limit. Workers can also own surplus-sharing shares, either by buying them off investors or the firm itself, or in lieu of ploughed back bonuses. This further aligns their interests with external investors.

The central idea here is that the bonus will automatically change as value-added and hence surplus (profit) change, while keeping the interests of the workers and all investors aligned far more strongly than if only some of the investors had control and there was a traditional fixed-wage structure with capital bearing most of the risk.

During a transition phase from traditional capitalist control (Erdal, 2011), fixed Base Pay might have to start as a high fraction of workers' expected total remuneration, then gradually be reduced: due to their lower wealth, workers are often far more risk-averse than entrepreneurs, at least initially, and it can take time, training and good experience to change attitudes and "acclimatise" workers to variable incomes, even though these incomes will be potentially higher and more under their control (Ridley-Duff, 2018). During such a transition phase, because of the weaker link between workers' and investors' incomes, it might be reasonable (or even necessary) for investors to also have voting rights, again decreasing as the transition to more pronounced surplus sharing progressed, and trust between the two groups became established.

Illustrative worked examples are presented in the Appendices A1-A7 below, e.g. the conversion from capitalist control, what happens when the surplus rises, or how the value-added split changes when the number of workers or the amount of investment is increased.

\section{Emergency or transitional voting rights for investors}

To further protect investors, following any year when dividends were below some pre-agreed target level[7], shares could gain temporary voting rights. Investors could then effect changes in management to get the firm back on track. Many variants of this are possible, for example, share vote weightings could be gradually tapered towards zero as the surplus increased. In any case, investors could always have the right to speak at general meetings (even if they had no voting rights), so their opinions, knowledge, preferences and collective wisdom could still feed into and improve the running of the firm.

Giving both workers and shares voting rights (e.g. "one slice one vote") might be attractive to some companies and investors, perhaps as a hybrid, transitional or trial arrangement - a confidence-building stepping stone towards democratic worker control[8]. Such a hybrid company where more than half the surplus (hence slices) went to bonuses would still be controlled by the workers. Actually, depending on alliances between different shareholders, it could even be possible for workers to effectively control a company in which there were substantially fewer worker slices than "investor" slices (a.k.a. shares), especially if some of the workers owned shares too - i.e. were themselves investors. However, a more capital-intensive company, with relatively few worker slices compared with investor slices, would be easier for an organised bloc of investors to control. Nevertheless, because of the surplus-sharing arrangement, if the investors aimed to maximise their own income per share, they would still also be indirectly working to maximise the average income of workers, thanks to the built-in locking together of the two kinds of earnings.

\section{Reinvestment of a portion of bonuses or dividends}

Reinvestment of a certain portion of bonuses or dividends would increase reserves and help the firm to grow. Reinvestment of bonuses would also smooth out pay fluctuations and prevent workers becoming over-dependent on high bonuses in good years then
Overcoming the capital investment hurdle 
experiencing problems in bad years. It would also reduce the anxiety and expectations surrounding bonuses.

There are various ways in which reinvestment could be implemented. One method could be by allocating new shares in exchange for bonuses or dividends at an agreed price, for example, using independent valuation, or a pre-agreed valuation method such as that in Appendix A5. More pragmatically, shares could be allocated at prices individual workers and investors (existing or new) were actually willing to offer, for example via some kind of open auction or sealed bids system, perhaps within a pre-agreed price range, or up to a pre-agreed target reinvestment. Many variants are possible, including, if needed, a compulsory component. To protect against undue "dilution" (Ellerman, 2015), share sales above a certain limit could be subject to approval by the majority of workers, and maybe also the majority of existing surplus-sharing shares.

\section{Worker capital stakes}

As discussed above, the evidence suggests that employee ownership and participation in management improve productivity in a mutually reinforcing manner (Blasi et al., 2017; McDonnell, 2012). Reinvestment can help workers build up and hold a pre-agreed minimal capital stake while they work in the firm, to improve commitment and motivation, and to further align interests with longer-standing workers and other investors. Internal workerinvestors have a strong incentive to monitor other workers and the running of the firm on behalf of external investors. They also have an incentive to prevent or report potential loopholes being exploited (e.g. over-generous expenses, excessively prolonging depreciation schedules to unjustifiably raise value-added, part-timers masquerading as full-timers or even "phantom" workers made up in order to raise the number of worker slices $k W$ by inflating the number of full-time equivalent workers $W$ ). Such abuses would also be minimised by the incentive to keep credible the option of raising further capital in the future, and the desire to be able to extract one's own personal capital stake upon leaving. Playing the "long game" means current investors must be given a good long-term rate of return. As mentioned above, there could also be limits on changes to the total fraction of surplus going to workers, beyond which external shareholder approval would be needed.

\section{Secondary market in shares}

In addition, surplus-sharing shares would be more attractive if there was a credible way of selling them on, which would also allow workers owning them to spread their risks or to cash out. To facilitate the sale of shares, a "secondary" market would need to be set up (perhaps via some kind of trust, investment club, investment bank, government agency, or organised by a federation of similar firms). Moreover, a firm could buy back its surplus-sharing shares in good years, if it was safe to reduce its reserves. This could occur via a sealed bids system in reverse, i.e. buy back the most cheaply offered shares first, up to a pre-agreed maximum value or ceiling price. Share prices in the secondary market could also (optionally) be used to help in the valuation of new surplus-sharing shares issued in exchange for reinvested bonuses or dividends - and vice versa.

Non-voting surplus-sharing shares could also be a useful tool to help ease the repurchase obligation liability of US ESOPs - their legal requirement to repurchase the shares of employees who leave the firm or retire (Cleary et al., 2018). The resulting financial stresses can be particularly severe when a surge of retirees occurs after a large increase in the value of a firm's shares. This has contributed to the (effective) "degeneration" of a number of firms away from majority employee ownership (Baker et al., 2015), although, typically, individual circumstances are multi-causal. Some of these ESOP firms have even failed completely. Other ESOP firms have side-stepped the repurchasing of shares by instead floating some or all of them on a stock exchange - a recent example is Mayville Engineering, Wisconsin, which is, however, at the time of writing, still approximately 70 per cent employee owned (Nathan Elwell, Lincoln Churchill 
Advisors, personal communication). Although partial flotation is compatible with maintaining majority employee ownership in the short term, if repeated often enough, the process could cause gradual conversion back towards traditional capitalist/investor control. This could be neatly avoided by floating non-voting surplus-sharing shares instead of voting ordinary shares, and relying on the formers' locking of dividends to bonuses, emergency voting rights, and the productivity benefits of employee ownership and participation ("ownership culture"), to both protect and encourage investors.

\section{Full recognition of equity}

A further advantage of having (normally) non-voting surplus-sharing shares, and the clean separation-with-alignment of control and ownership that this achieves, is that if a firm's market value rises or falls, its equity (sale price - liabilities) is explicitly recognised and allocated differentially and fairly between particular worker-owners and other investors, depending on their past contributions and past risk-taking. This could potentially help worker-owned and controlled firms, such as future Tower Collieries (O'Sullivan, 2001) or the Mondragon Co-ops, take on new or younger workers, without them having to put in an initial capital stake equivalent to the current value of that of the original worker-owners (which in a successful firm may well have been revalued hugely upwards to reflect present day reality: a challenging and sometimes insurmountable entry barrier for most young and non-wealthy individuals). The new workers could also safely be given the same democratic rights as the founders or more veteran owners, without the risk of the latter being "ripped off". Thus outside contractors or non-voting "second class citizen" workers would not need to be employed, as commonly occurs, including in both the examples just mentioned.

If new equipment was needed, but the working capital of the firm was insufficient, further outside investment could be sought, in exchange for more surplus-sharing shares, again using valuation, negotiation and/or sealed bids or other auctioning methods to agree a share price or prices. The combination of proper full recognition of equity, the automatic locking together of investors' and workers' interests and individual exit mechanisms available via a secondary market, would counter the pressures towards degeneration.

\section{Summary}

To recap: we deduct a pre-agreed fixed "base" component of wages from value-added (sales minus non-labour costs), to obtain the surplus. Each share gets one slice of surplus, and each worker, on average, gets a pre-agreed number of slices $(k)$. The surplus is split equally between all slices. Put simply, for the purposes of splitting the surplus, each "average" worker is equivalent to a pre-agreed number of shares. The mechanism is inherently very flexible. It allows changes in both the number of workers and the amount of capital invested, without requiring frequent renegotiation between workers and investors about what portions of the value-added "cake" go to each group. This could help avoid "perverse" incentives (see Appendix A7), and so could be a potential (optional) improvement on the "FairShares" and related models upon which the scheme is partly based (Major, 1996, 1998; Ridley-Duff, 2015a, b, 2018; Ridley-Duff and Bull, 2016). Over the longer term, however, or if radical transformations are needed in the company, or if market conditions change substantially, the number of surplus slices per average worker $(k)$ may itself need to be renegotiated, for example to help recruit new investors or more highly skilled workers.

As some scholars have noted, the spread of "truly" democratic firms could be a major step towards solving some of the world's problems (Calvert Jump, 2018; Guinan and Hanna, 2018) - the surplus-sharing mechanism can enable this to happen. This surplus-sharing mechanism, as outlined here, should solve both the underinvestment and degeneration problems often experienced by worker-controlled firms, by opening up a much-needed route for external, non-controlling but risk-sharing "ethical" equity investment into such firms
Overcoming the capital investment hurdle 

diversify part of their own holdings out of their company, spreading their risks (or allow them to extract all of their equity fairly, if they leave or retire, without causing cash flow difficulties to the firm). It should enable capitalist firms to be converted to democratic worker control, while actually improving investor protection, via locking dividends to bonuses, by incentivising and motivating the workforce, and by giving workers a stake in their own companies. As well as encouraging more widespread and sustainable adoption of workplace democracy, this kind of surplus sharing should promote optimal capital-labour ratios, and hence "dynamic" productivity and growth. It has long been assumed that it is impossible to have both workplace democracy and sufficient capital investment, sustainably over long periods, but even a few convincing counter-example experiments with surplus sharing could undermine this assumption, revolutionising our economic system and transforming our political landscape.

Markets do not need capitalism: they pre-date it by many millennia (Polanyi, 2002/1944). Our proposal is a step towards replacing capitalism with economic democracy, while regaining the benefits of the decentralised economic decision-making and resource allocation provided by trade and markets. Supply, demand and various auctioning methods would still help set prices, but without unaccountable capitalist elites running the show. Prices would still send signals about investment opportunities and priorities. Government intervention would of course still be needed to correct inevitable market failures (e.g. natural monopolies), and to prevent environmental "dumping", to provide safety nets, to redistribute wealth, and to give overall democratic direction, prioritisation and co-ordination via planning. However, this intervention should be far more effective than in the past, because of the internet and vast computing resources that were not available to centrally planned economies decades ago, including super-computers, neural networks, AI and powerful optimisation techniques. Likewise, fine-tuning all the details will require considerable experimentation which can be expedited by unequivocal government support. But there is a growing consensus that nurturing a more democratic economic system to counter the destructive excesses of contemporary shareholder capitalism is now an urgent priority.

\section{Acknowledgements}

The authors would like to thank anonymous reviewers, the NCEO, Rob Calvert Jump and Rory Ridley-Duff for considerable and insightful input. The authors also owe an enormous debt of gratitude to Roger McCain for originally proposing an essential core part of the central idea in this article, albeit in a slightly different formulation, namely locking dividends per share to average compensation per employee (McCain, 1977, 1999). The authors would also like to thank him for reading and incisively criticising an early version of this article, and two earlier publications by GM (cited in the Bibliography), and for numerous other helpful suggestions. This work would not have been possible without him.

\section{Notes}

1. US Federal law requires a one-share-one-vote employee secret ballot in ESOPs before all important company decisions such as recapitalisation, liquidation or sale of firm, etc. (anonymous communication from reviewer).

2. Partial or complete, individualised via shares or internal capital accounts, and/or more collective (via trusts holding shares on behalf of workers, or via common ownership).

3. Either worker representation or worker control.

4. This empirical evidence is not unequivocal: e.g. Bellmann and Möller (2016) and Kranz and Steger (2016). 
5. Full-time equivalent or FTE; someone working half a normal week counts as half a worker.

6. "Value-added" here should not be confused with any increase in market value or rise in equity: that is capital gains!

7. E.g. if the firm made a nominal loss, i.e. the surplus was negative, because the value-added did not exceed fixed base wages.

8. The logic would be that, under surplus sharing, both workers and investors are bearing comparable income risk, per share (slice). If the firm went bust, however, workers could in addition lose their livelihoods whereas investors would "only" lose their original investment, but hopefully their risks would be spread and their remaining wealth would cushion them. Which of the two losses is more serious is much argued, and depends on overall circumstances.

\section{References}

Bakan, J. (2004), The Corporation: The Pathological Pursuit of Profit and Power, Free Press, New York, NY.

Baker, D., Dietrich, B., Kornfeld, J.L., Lifson, S. and Rosen, C. (2015), "Repurchase obligations and distribution policy issues", in Rosen, C. (Ed.), Don't Do That. Common Mistakes in Operating an ESOP and What to Do About Them, National Center for Employee Ownership, Oakland, CA, pp. $43-66$.

Barandiaran, X. and Lezaun, J. (2017), "The Mondragón experience”, in Michie, J., Blasi, J.R. and Borzaga, C. (Eds), The Oxford Handbook of Mutual, Co-operative, and Co-owned Business, Oxford University Press, Oxford, pp. 279-294.

Barrott, C., Brown, M., Cumbers, A., Hope, C., Huckfield, L., Calvert Jump, R., McInroy, N. and Shaw, L. (2017), "Alternative models of ownership. Report to the shadow chancellor of the exchequer and shadow secretary of state for business, energy and industrial strategy", Labour Party, London, available at: https://labour.org.uk/wp-content/uploads/2017/10/Alternative-Models-ofOwnership.pdf

Bellmann, L. and Möller, I. (2016), "Are firms with financial participation of employees better off in a crisis? Evidence from the IAB establishment panel survey”, Management Revue, Vol. 27 No. 4, pp. 304-320.

Birchall, J. (2017), “The performance of member-owned businesses since the financial crisis of 2008”, in Michie, J., Blasi, J.R. and Borzaga, C. (Eds), The Oxford Handbook of Mutual, Co-operative, and Co-owned Business, Oxford University Press, Oxford, pp. 570-584.

Blasi, J.R., Freeman, R.B. and Kruse, D.L. (2017), "Evidence: what the US research shows about worker ownership", in Michie, J., Blasi, J.R. and Borzaga, C. (Eds), The Oxford Handbook of Mutual, Co-operative, and Co-owned Business, Oxford University Press, Oxford, pp. 211-226.

Bryson, A. and Freeman, R.B. (2010), "How does shared capitalism affect economic performance in the United Kingdom?", in Kruse, D.L., Freeman, R.B. and Blasi, J.R. (Eds), Shared Capitalism at Work: Employee Ownership, Profit and Gain Sharing, and Broad-Based Stock Options, University of Chicago Press, Chicago, IL and London, pp. 201-224.

Calvert Jump, R. (2018), "Better models of business ownership”, in McDonnell, J. (Ed.), Economics for the Many, Verso, London, pp. 85-97.

Cleary, T., De Craene, P., Kornfeld, J.L., Mathews, A.I., Nicholson, N., Roback, T.J., Rodgers, L., Rusch, K.T., Shuler, P., Wiefek, N. and Wright, K.B.R. (2018), The ESOP Repurchase Obligation Handbook, 5th ed., National Center for Employee Ownership, Oakland, CA.

Ellerman, D. (2015), The Democratic Worker-Owned Firm: A New Model for the East and West, Routledge, New York, NY.

Employee Ownership Association (2012), "Employee ownership impact report”, Employee Ownership Association, London, available at: https:/employeeownership.co.uk/wp-content/uploads/TheImpact-Report.pdf (accessed 10 August 2019).

Erdal, D. (2011), Beyond the Corporation: Humanity Working, Bodley Head, London. 
Fakhfakh, F. and FitzRoy, F. (2018), "Is profit sharing good for the environment? Positive evidence from French firms", Journal of Participation and Employee Ownership, Vol. 1 Nos 2/3, pp. 128-143.

Fakhfakh, F., Pérotin, V. and Gago, M. (2012), "Productivity, capital, and labor in labor-managed and conventional firms: an investigation on French data", ILR Review, Vol. 65 No. 4, pp. 847-879.

Guinan, J. and Hanna, T.M. (2018), "Democratic ownership in the new economy”, in McDonnell, J. (Ed.), Economics for the Many, Verso, London, pp. 108-125.

Hawken, P. (2010), The Ecology of Commerce: A Declaration of Sustainability, Revised ed., Harper Business, New York, NY.

IPPR (2018), Prosperity and Justice. A Plan for the New Economy, Institute for Public Policy Research, Cambridge, available at: www.ippr.org/files/2018-08/1535639099_prosperity-andjustice-ippr-2018.pdf

Klein, N. (2007), The Shock Doctrine: The Rise of Disaster Capitalism, Metropolitan Books, New York, NY.

Knell, J. (2008), "Share value: how employee ownership is changing the face of business", All Party Parliamentary Group on Employee Ownership, London, available at: www.equityincentives.co. uk/resources/APPG-share-value-report.pdf

Kranz, O. and Steger, T. (2016), "Resurrected, recovered, but still didn't survive? A case study on the viability of employee-owned companies”, Management Revue, Vol. 27 No. 4, pp. 234-260.

Kruse, D.L., Freeman, R.B. and Blasi, J.R. (2010), Shared Capitalism at Work: Employee Ownership, Profit and Gain Sharing, and Broad-Based Stock Options, 1st ed., University of Chicago Press, Chicago, IL.

Logue, J. (2006), "Economics, cooperation, and employee ownership: the Emilia Romagna model - in more detail", available at: http://staging.community-wealth.org/sites/clone.community-wealth. org/files/downloads/article-logue_0.pdf (accessed 10 August 2019).

McCain, R.A. (1977), “On the optimum financial environment for worker co-operatives”, Zeitschrift für Nationalökonomie, Vol. 37 No. 34, pp. 355-384.

McCain, R.A. (1999), "Toward sustainable external finance for democratic enterprise", Research Conference of International Co-operative Alliance, Quebec.

McDonnell, D. (2012), Democratic Enterprise: Ethical Business for the 21st Century, Co-operative Enterprise Education Scotland, Glasgow.

Major, G. (1996), "Solving the under-investment and degeneration problems of worker co-ops", Annals of Public and Co-operative Economics, Vol. 67 No. 4, pp. 545-601.

Major, G. (1998), "The need for NOVARS (non-voting value added sharing renewable shares)", Journal of Co-operative Studies, Vol. 31 No. 2, pp. 57-72.

Meyers, J.S.M. (2011), "Employee ownership, democratic control, and working class empowerment”, in Carberry, E.J. (Ed.), Employee Ownership and Shared Capitalism: New Directions in Research, Labor and Employment Relations Association, Champaign, IL, pp. 113-145.

Michie, J. (2017), “The importance of ownership”, in Michie, J., Blasi, J.R. and Borzaga, C. (Eds), The Oxford Handbook of Mutual, Co-operative, and Co-owned Business, Oxford University Press, Oxford, pp. 3-13.

Michie, J., Blasi, J.R. and Borzaga, C. (2017), The Oxford Handbook of Mutual, Co-operative, and Co-owned Business, Oxford University Press, Oxford.

National Center for Employee Ownership (2019a), ESOPs by the Numbers, National Center for Employee Ownership, Oakland, CA, available at: www.nceo.org/articles/esops-by-the-numbers

National Center for Employee Ownership (2019b), A Statistical Profile of Employee Ownership, Oakland, CA, available at: www.nceo.org/articles/statistical-profile-employee-ownership

Norton, M. and Ariely, D. (2011), "Building a better America: one wealth quintile at a time", Perspectives on Psychological Science, Vol. 6 No. 1, pp. 9-12. 
Nuttall, G. (2012), Sharing Success: The Nuttall Review of Employee Ownership, Department of Business, Innovation and Skills, UK Government, London, available at: www.gov.uk/government/ publications/nuttall-review-of-employee-ownership

O'Sullivan, T. (2001), Tower of Strength: The Story of Tyrone O'Sullivan and Tower Colliery, Mainstream Publishing, Edinburgh.

Oxfam (2018), Reward Work not Wealth, Oxfam International, Oxford, available at: https:/oxfamilibrary. openrepository.com/bitstream/handle/10546/620396/bp-reward-work-not-wealth-220118-en.pdf

Ozerow, D. and Croucher, R. (2014), "Workers' self-management, recovered companies and the sociology of work”, Sociology, Vol. 48 No. 5, pp. 989-1006.

Pencavel, J. (2013), "Worker co-operatives and democratic governance”, in Grandori, A. (Ed.), Handbook of Economic Organization, Edward Elgar, Northampton, MA, pp. 462-480.

Pendleton, A. (2011), "Employee ownership in Britain: diverse forms and diverse antecedents", in Carberry, E.J. (Ed.), Employee Ownership and Shared Capitalism, Labor and Employment Relations Association, Champaign, IL, pp. 311-340.

Pendleton, A. and Robinson, A. (2017), "Employee ownership in Britain today", in Michie, J., Blasi, J.R. and Borzaga, C. (Eds), The Oxford Handbook of Mutual, Co-operative, and Co-owned Business, Oxford University Press, Oxford, pp. 426-444.

Pérotin, V. (2017), "Worker co-operatives: good, sustainable jobs in the community”, in Michie, J., Blasi, J.R. and Borzaga, C. (Eds), The Oxford Handbook of Mutual, Co-operative, and Co-owned Business, Oxford University Press, Oxford, pp. 131-144.

Pérotin, V. and Robinson, A. (2004), Employee Participation, Firm Performance and Survival: Advances in the Economic Analysis of Participatory and Labor-Managed Firms, Elsevier, Oxford.

Polanyi, K. (2002/1944), The Great Transformation: The Political and Economic Origins of Our Time, 2nd ed., Beacon Press, Boston, MA.

Ridley-Duff, R. (2015a), The Case for FairShares: A New Model for Social Enterprise Development and the Strengthening of the Social and Solidarity Economy, CreateSpace Independent Publishing Platform, Charleston, SC.

Ridley-Duff, R. (2015b), "The FairShares model - an ethical approach to social enterprise?", Econviews Review of Contemporary Business, Entrepreneurship and Economic Issues, Vol. 28 No. 1, pp. 43-66.

Ridley-Duff, R. (2018), "The internationalisation of FairShares model: where agency meets structure in US and UK company law", in Boeger, N. and Villiers, C. (Eds), Shaping the Corporate Landscape, Hart Publishing, Oxford, pp. 309-332.

Ridley-Duff, R. and Bull, M. (2016), Understanding Social Enterprise: Theory and Practice, 2nd ed., Sage Publications, London.

Roberts, C.C. (2000), "Employee involvement in UK bus company ownership in the post deregulation era”, paper presented at the Universities Transport Study Group, 32nd annual conference, Liverpool, 5-7 January 2000.

Rosen, C. (2011), Working Better, National Center for Employee Ownership, Oakland, CA.

Scholtz, T. and Schneider, N.e. (2016), Ours To Hack and Own: The Rise of Platform Cooperativism, a New Vision for the Future of Work and a Fairer Internet, OR Books, New York, NY/London.

Spear, R. (1999), "The rise and fall of employee-owned UK bus companies", Economic and Industrial Democracy, Vol. 20 No. 2, pp. 253-268.

Srnicek, N. (2018), "Platform monopolies and the political economy of AI", in McDonnell, J. (Ed.), Economics for the Many, Verso, London, pp. 152-163.

Vieta, M. (2010), “The social innovations of autogestión in Argentina's worker-recuperated enterprises: cooperatively reorganizing productive life in hard times", Labor Studies Journal, Vol. 35 No. 3, pp. 295-321.

Vieta, M. (2012), "From managed employees to self-managed workers: the transformations of labour at Argentina's worker-recuperated enterprises", in Atzeni, M. (Ed.), Alternative Work Organizations, Palgrave Macmillan, London, pp. 129-156.
Overcoming the capital investment hurdle 


\section{Appendix 1. Conversion process}

Suppose a firm has 100 workers paid an average of $£ 40 \mathrm{k}$ each per year, totalling $£ 4 \mathrm{~m}$, and suppose it makes a profit of $£ 1 \mathrm{~m}$. Its value-added $=$ sales - non-labour $\operatorname{costs}=$ wages + profit $=£ 4 \mathrm{~m}+$ $£ 1 \mathrm{~m}=£ 5 \mathrm{~m}$. It could be converted to democratic worker control with surplus sharing as follows (for example): convert the existing shares into $1 \mathrm{~m}$ surplus-sharing shares, which yielded a dividend of $£ 1$ each in the past year (giving a total dividend, or profit, of $£ 1 \mathrm{~m}$ still). Say the average "base" (fixed component of) salary is retrospectively agreed to be $£ 20 \mathrm{k}^{* *}$, making the average bonus $£ 20 \mathrm{k}$ in the year just gone (so base + bonus add to $£ 40 \mathrm{k}$, keeping average total pay the same as before). (**The base rate of pay is $£ 10$ an hour; $40 \mathrm{~h} \times 50$ weeks $=2000$ hours per year, $2000 \times £ 10=£ 20 \mathrm{k}$ ). This means the bonus of the average worker is equivalent to $k=20,000$ shares, as each share yielded a dividend of $£ 1$ and the average worker received (retrospectively) a (nominal) bonus of $£ 20 \mathrm{k}$. The workers are then allocated an average of 20,000 surplus slices each, shared out depending on each individual's actual pay rate, but so there are a total of 100 workers $\times 20,000$ slices per worker $=2 \mathrm{~m}$ (worker) slices. The total bonus is $100 \times £ 20 \mathrm{k}=2 \mathrm{~m} \times £ 1=£ 2 \mathrm{~m}$; see Figure A1(a). So total base pay + total bonus + total dividend (profit) $=£ 2 \mathrm{~m}+£ 2 \mathrm{~m}+£ 1 \mathrm{~m}=£ 5 \mathrm{~m}=$ original value-added. The numbers add up: surplus $=$ value-added - total base pay $=£ 5 \mathrm{~m}-£ 2 \mathrm{~m}=£ 3 \mathrm{~m}$. This is split equally between $3 \mathrm{~m}$ slices ( $2 \mathrm{~m}$ worker slices $+1 \mathrm{~m}$ shares), each therefore receiving $£ 1$. For now, with this number of workers, two-thirds of the surplus goes on bonuses and one-third of the surplus goes on dividends (profits; see Figure A1(a)). The average worker gets $£ 20 \mathrm{k}$ base pay and $£ 20 \mathrm{k}$ bonus $=£ 40 \mathrm{k}$ in all, same as before, for the year just gone.

\section{Appendix 2. Surplus sharing process, when value-added changes}

Suppose in the next year the value-added increases to $£ 6.5 \mathrm{~m}$ (see Figure A1(b)). The base pay remains the same, but now the surplus $=$ value-added - base pay $=£ 6.5 \mathrm{~m}-£ 2 \mathrm{~m}=£ 4.5 \mathrm{~m}$. This is divided equally between $3 \mathrm{~m}$ slices (worker slices + surplus-sharing shares), each slice therefore getting $£(4.5 / 3)=£ 1.50$. The dividend per surplus-sharing share is therefore now $£ 1.50$, and the average worker receives $k=20,000$ slices $\times £ 1.50$ per slice $=£ 30 \mathrm{k}$ in bonus. So the average worker receives $£ 20 \mathrm{k}$ base pay $+£ 30 \mathrm{k}$ bonus $=£ 50 \mathrm{k}$ in all. The total bonus is $100 \times £ 30 \mathrm{k}=£ 3 \mathrm{~m}$, total base pay is still $£ 2 \mathrm{~m}$, and total dividend (profit) is now $£ 1.5 \mathrm{~m}$ (all three of which add up to $£ 6.5 \mathrm{~m}$, = the value-added $=$ sales minus non-labour costs).

\section{Appendix 3. Change in the number of workers}

Figure A2(a) shows what would happen if the number of workers is increased by 50 per cent to 150, and (for illustrative purposes) the value-added as a result rises to $£ 7 \mathrm{~m}$. There are now 150 workers $\times(20,000$ surplus-slices per worker) $=3 \mathrm{~m}$ worker surplus-slices. The average base pay is still £20k per worker, so total base pay is now $£ 20 \mathrm{k} \times 150=£ 3 \mathrm{~m}$, instead of $£ 2 \mathrm{~m}$. The surplus is value-added - total base pay $=£ 7 \mathrm{~m}-£ 3 \mathrm{~m}=£ 4 \mathrm{~m}$, and because the total number of slices (worker surplus slices + shares) has increased to $4 \mathrm{~m}$, the surplus per slice (or dividend per share) is $£ 4 \mathrm{~m} /(4 \mathrm{~m}$ slices) $=£ 1$ (again!). If the firm takes on 50 extra staff, starting from the situation in Appendix $1 £ 7 \mathrm{~m}$ is actually the "break-even" valueadded, above which workers would start to earn more. Other things being equal, workers would therefore be likely to vote for this change in staff numbers, provided value-added was projected, as a result, to rise to more than $£ 7 \mathrm{~m}$. That way, their incomes would rise (and with them, automatically, investors' dividend per share).

\section{Appendix 4. Change in the amount of investment, hence the number of surplus-sharing shares}

Starting from the original situation in Appendix 1, suppose that outside capital is invested, in exchange for another million surplus-sharing shares, so there are now $2 \mathrm{~m}$ shares in all, giving a total of $4 \mathrm{~m}$ slices $(=2 \mathrm{~m}$ share slices $+2 \mathrm{~m}$ worker-slices). Suppose also, again for illustrative purposes, that as a consequence, the value-added now rises to $£ 6 \mathrm{~m}$. The resulting distribution of income is shown in Figure A2(b): the surplus is value-added - total base pay $=£ 6 \mathrm{~m}-£ 2 \mathrm{~m}=£ 4 \mathrm{~m}$ and the surplus per slice is $£ 4 \mathrm{~m} /(4 \mathrm{~m}$ slices $)=£ 1$. This is the dividend per share. The average bonus per worker is $£ 2 \mathrm{~m} / 100$ workers $=£ 20 \mathrm{k}$ per worker. Again, this situation is the "break-even" value-added. So, other things being equal, the workers would probably vote for this change in investment, provided it was likely to result in a rise in value-added beyond $£ 6 \mathrm{~m}$ (in this case), making them, and hence investors, all better off.

Increases in the number of workers or the amount of investment should both raise value-added, if done right; the real decision is whether this rise would be sufficient to leave everyone better off or not, 
(b)

Value Added $=£ 6.5 \mathrm{~m}$

(a)

Value Added $=£ 5 \mathrm{~m}$

(all 3 boxes)

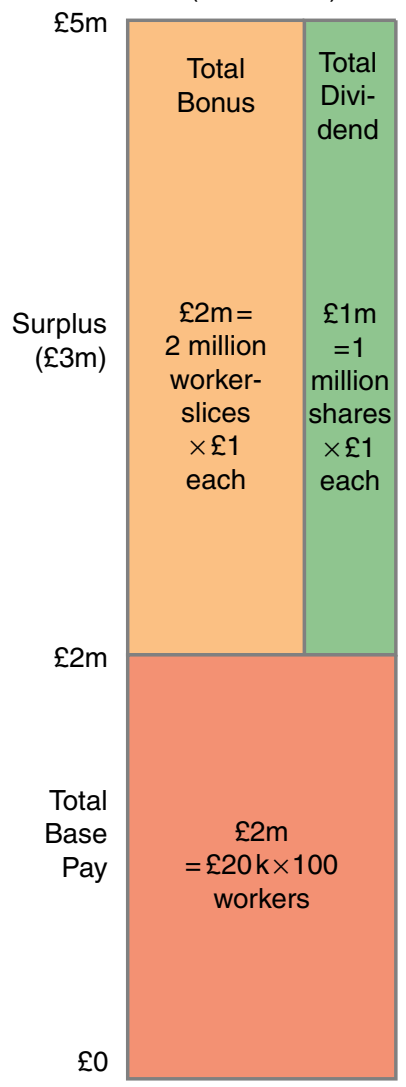

(all 3 boxes)

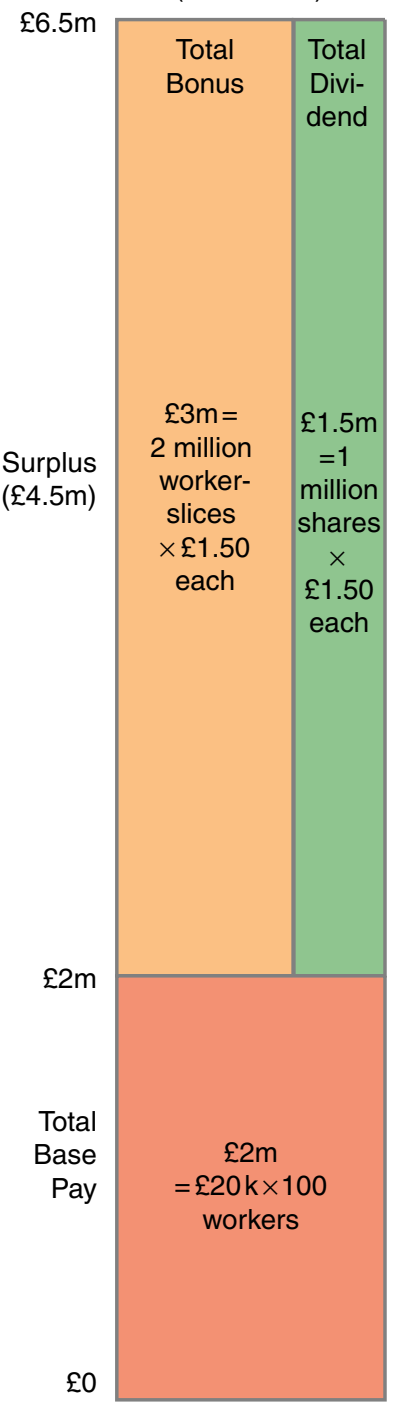

Overcoming the capital investment hurdle
Figure A1.

Conversion process (a) and increase in value-added (b)

by raising value-added per slice - e.g. because of economies of scale or improved productivity, or whether diminishing returns would set in in. Either way, workers, by pursuing their own interests, would automatically look after the interests of the investors too.

\section{Appendix 5. Share valuation}

A simple valuation formula involves pre-agreeing a target fractional annual rate of return $\mathrm{R}$, taking account of the riskiness of the investment and the opportunity costs (e.g. interest rates). The share price is then set to the present discounted value of future dividends. This can be shown (in a simple case) to be (predicted annual dividend)/R, although there are more complicated variants also factoring in projected rate and pattern of growth. Let us say the dividend per share is $£ 1$, and that a reasonable 
JPEO

Figure A2.

Change in the number of workers (a) or shares, following more investment (b) (a)

No. of workers

increases to 150

Value Added $\rightarrow £ 7 \mathrm{~m}$

(all 3 boxes)

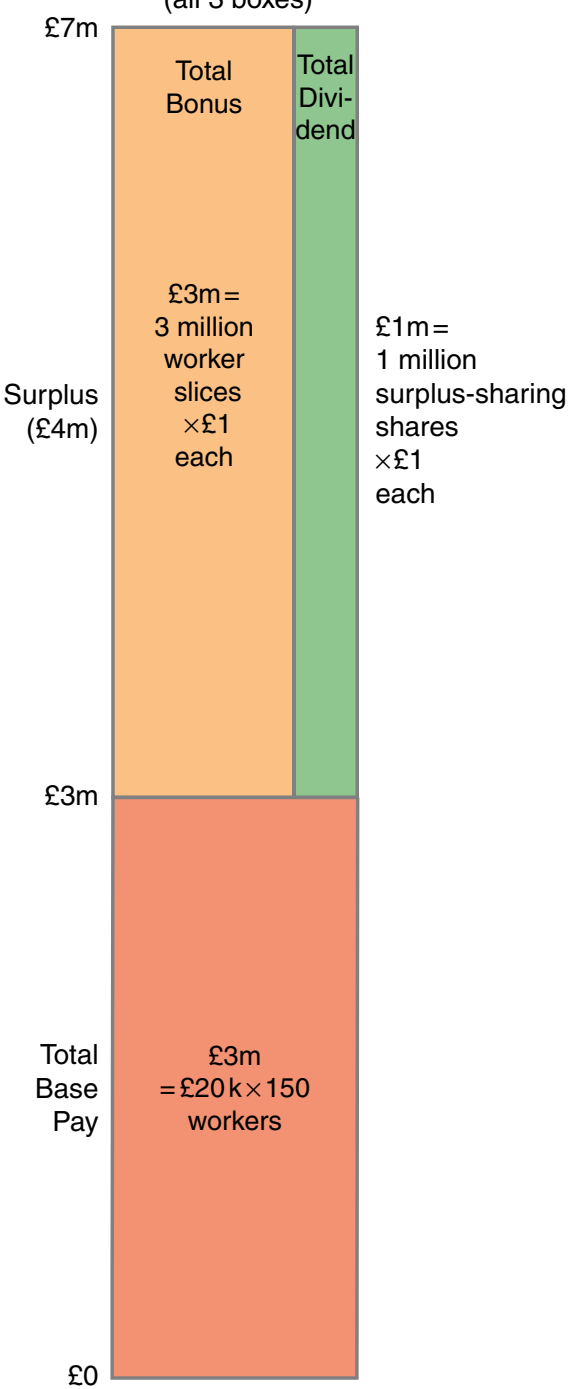

(b)

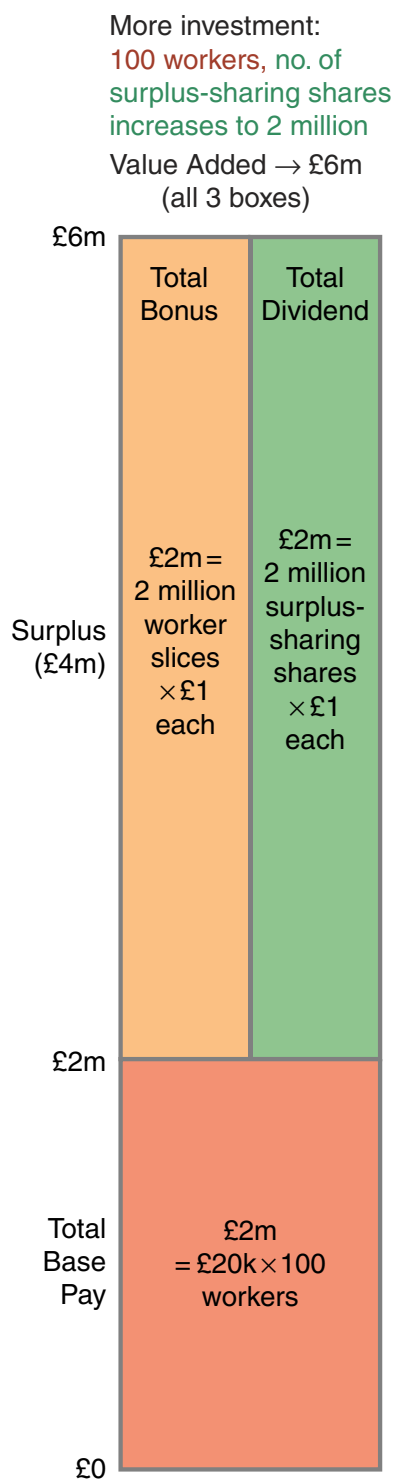

target fractional rate of return is agreed between investors and workers to be 10 per cent $(=0.1)$, based on projected growth, profit volatility and other risks, interests rates and wider stock market performance. The share price would then be $£ 1 / 0.1=£ 1 \times 10=£ 10$. In other words, one new surplussharing share would be issued per $£ 10$ (re-)invested.

\section{Appendix 6. Capital gains fraction}

It makes sense to incentivise the workers to strive towards long term as well as short term gains, by encouraging them to increase the value of the company, for example, by innovation or by investing 
"sweat equity" (free labour). Therefore, if the firm's valuation showed a consistent increase over more than some pre-agreed number of years, to reward the workers, a pre-agreed "capital gains fraction" of the increase in value could be allocated to them in the form of free surplus-sharing shares. These could be divided up in proportion to the workers' surplus slices, or by some other democratically-decided method reflecting their contributions. The capital gains fraction could be set at (number of workerslices)/(total number of slices). This way workers and investors would share longer term capital gains in essentially the same way they shared shorter-term surpluses, further aligning their interests, and neatly recognising different forms of investment, such as money, effort, time, danger and ingenuity.
Overcoming the capital investment hurdle

\section{Appendix 7. Why not simply divide the surplus into fixed bonus and dividend fractions?}

Earlier related proposals (NOVARS, profit shares: Major, 1996, 1998; FairShares: Ridley-Duff, 2015a, b, 2018) divide the surplus or profit, after deducting base wages from value-added, into pre-agreed bonus and dividend fractions. The bonus fraction is split among the workers, by a democratically agreed process, and the dividend fraction is split equally among the shares. The bonus and dividend fractions can in theory be renegotiated, for example if the company plans to raise new equity capital or expand its workforce. However, what if there is no agreement, or if the process turned out to be too cumbersome? Roger McCain (1999) pointed out that perverse incentives could arise, which could cause the firm to under-invest or under-recruit. For example, suppose for the sake of the argument that doubling the workforce while leaving capital fixed is predicted to double the surplus - ignoring any diminishing returns that might set in if capital became a bottleneck. Under these rather rigid bonus/dividend fractions schemes, the workers would receive the same bonuses on average as now (so what is in it for them?), yet the dividend on each share would double. (Is this not unfair? What extra have the investors put in to deserve this?). What is the incentive for the workers to undergo the disruption, other than maybe charity or working for the common good of society? In a not unlikely scenario of diminishing returns on capital, so that the surplus less than doubled, the decision would not be taken, as the workers would actually be worse off. The firm would thus fail to take an opportunity to expand, even though its surplus would have gone up and its shareholders would have been better off. The problem is, they would have been "too" better off - at the expense of the workers. (For the sake of the argument, this assumes only small investment shareholdings by workers themselves). In general, including "marginal" cases (with small changes), if the number of workers increases by a factor $\mathrm{f}$, but the surplus increases by a smaller factor g, although the share dividend increases, the workers' bonuses will decrease. Unless they have substantial shareholdings, workers are likely vote against such a change.

The outcome would be more beneficial to the firm under the much closer alignment of worker and investor interests given by the surplus-sharing scheme proposed in this article, with the average worker equivalent to $\mathrm{k}$ shares. The workforce expansion would go ahead, as both workers and investors would automatically benefit fairly, to the same relative extent. Starting with $S$ shares and $W$ workers, we proposed to double the workforce to $2 W$. If the original surplus is $P$, the new surplus is predicted to be $2 P$. The original surplus is split into $(S+k W)$ equal slices. The new number of slices would be $(S+2 k W)$. The new dividend (one slice per share) would be $2 P /(S+2 k W)$, and the new average bonus would be $k$ times that, namely $2 k P /(S+2 k W)$. The surplus has doubled, but the number of slices into which it is divided has less than doubled (because the number of shares $S$ is unchanged), meaning the surplus per slice goes up and everyone, investors and workers alike, would be better off. The workers would therefore vote for this change. The argument is essentially the same if an $f$-fold increase in workforce leads to an f-fold increase in surplus (just substitute $f$ for 2). The new dividend (one slice per share) would rise to $f P /(S+f k W)$, and the new average bonus would be $k$ times that.

Under the "worker $=k$ shares" scheme in this paper, the workers would also vote for scenarios involving diminishing returns on capital, providing they (and hence the investors) were expected to be better off after crunching the numbers: i.e. provided the surplus is projected to go up by more than the total number of slices, i.e. the extra workers would make everyone better off. If the workforce increases $f$-fold, to $f W$ workers, the new number of slices would be $(S+k(f W))$. If the surplus increases $q$-fold to $q P$, the new dividend per share would be $q P /(S+k f W)$, and the average bonus would be $k$ times that. Provided new dividend $>$ old dividend, i.e. $q P /(S+k f W)>P /(S+k W)$, the workers would vote for the change. Simplifying, dividing both sides by $P$ and multiplying both sides by $(S+k f W$ ), gives $q>(S+f k W) /(S+k W)$, i.e. the intuitive condition for voting for the expansion is that the surplus has 
to increase by more-fold than the total number of slices does, so that surplus per slice increases, dividends go up, bonuses go up by the same fraction, and everyone is better off.

The same basic logic applies to increasing investment. Suppose new external investment could be made of extra capital that involved doubling the number of shares to $2 S$ (at a negotiated/fair share price). Suppose again that there are no diminishing returns (labour availability and skills are not limiting factors), and that this investment is also predicted to just double the surplus to $2 P$. With the fixed dividend fraction of NOVARS and FairShares, the dividend per share would be unaltered (twice the surplus divided by twice the number of shares), but the bonuses of all workers would be doubled (with no extra effort on their part!). Workers would benefit, but existing investors (those not buying new shares) would not. If diminishing returns applied (e.g. if labour was a limiting factor), surplus would less than double, and the existing investors would actually be worse off. So if they had any veto rights, they would be likely to exercise them. And if they could not, and were consequently disadvantaged, this would deter others investing in the future - or indeed in the first place (by "gaming" possible scenarios). So under "rigid" FairShare style bonus and dividend fractions, again there could be a potential conflict of interest between workers and investors, which could lead to underinvestment and under-expansion.

These potentially "perverse" incentives are again avoided by using the "average worker equivalent to $\mathrm{k}$ shares" scheme suggested in this article. Continuing the same example, after investing more capital and doubling the number of shares, the number of slices would increase from $S+k W$ to $2 S+k W$, so the dividend per share would now be $2 P /(2 S+k W)$, i.e. it would go up, because the surplus has doubled to $2 P$, but the total number of slices has less than doubled, due to $k W$ being fixed. The average bonus per worker would increase by exactly the same factor as the dividend does, so all investors and all workers would have exactly the same benefits and incentives. Even if there were diminishing returns to capital, the workers would decide to go ahead with the investment, providing it left them, and hence the original investors, better off. There would be no conflict of interest between the different groups. So if the investment was expected to increase surplus $q$-fold and resulted in the number of shares increasing $r$-fold, the workers would vote for such a change if dividend per share (and hence average bonus) increased, i.e. if $q P /(r S+k W)>P /(S+k W)$, i.e. $q>(r S+k W) /(S+k W)$. As with expanding the workforce, the fractional increase in surplus has to exceed the fractional increase in the number of slices.

Putting both types of change together: suppose we could increase the number of workers $f$-fold and (externally) invest at the same time, resulting in an $r$-fold increase in shares, together yielding a $q$-fold increase in surplus. Workers would vote for this provided surplus per slice (dividend per share) went up. New dividend $>$ old dividend if $q P /(r S+k f W)>P /(S+k W)$, i.e. $q>(r S+k f W) /(S+k W)$ : again, intuitively, the fractional increase in surplus has to exceed the fractional increase in the total number of slices, so that dividends go up, and bonuses go up with them.

The original investors are protected from additional investors or workers reducing their expected returns on capital by having their dividends locked to workers' bonuses, and hence their short and long-term interests are kept automatically aligned to those of the workers, largely obviating the need for voting rights - as long as the workers are wise enough to make good choices. If the surplus fell below a pre-agreed trigger level (such as going negative), emergency voting rights for the shares could kick in, providing another confidence-building layer of protection for investors.

\section{Corresponding author}

Guy Major can be contacted at: majorg@cardiff.ac.uk

For instructions on how to order reprints of this article, please visit our website: 